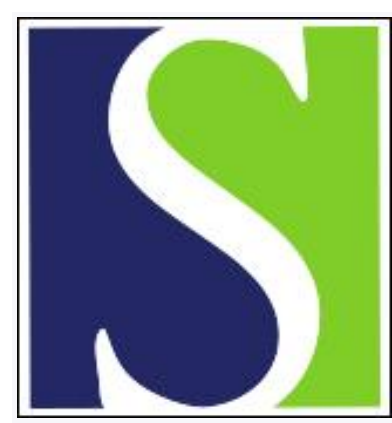

Scand J Work Environ Health 1998;24(1):18-29

https://doi.org/10.5271/sjweh.274

Issue date: Feb 1998

Effects of long-term organophosphate exposures on neurological symptoms, vibration sense and tremor amongst South African farm workers

by London L, Nell V, Thompson M-L, Myers JE

The following article refers to this text: 2004;30(5):362-370

Key terms: farm worker; long-term exposure; organophosphate

This article in PubMed: www.ncbi.nlm.nih.gov/pubmed/9562397

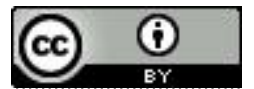




\title{
Effects of long-term organophosphate exposures on neurological symptoms, vibration sense and tremor among South African farm workers
}

\author{
by Leslie London, MD, ${ }^{1}$ Victor Nell, PhD, ${ }^{2}$ Mary-Lou Thompson, PhD, ${ }^{3}$ Jonathan E Myers, MD ${ }^{1}$
}

\begin{abstract}
London L, Nell V, Thompson M-L, Myers JE. Effects of long-term organophosphate exposures on neurological symptoms, vibration sense and tremor amongst South African farm workers. Scand J Work Environ Health 1998;24(1):18-29.
\end{abstract}

\begin{abstract}
Objectives This study assessed the relationship between long-term exposure to organophosphate insecticides and neurological symptoms, vibration sense, and motor tremor after control for the effect of past poisoning and acute exposure.

Methods This cross-sectional study included 164 pesticide applicators and 83 nonspraying reference workers on deciduous fruit farms. The workers were tested on the Vibratron II, on tests of dynamic and static tremor, and for a set of neurological and "dummy" symptoms. Exposure was derived with the use of a job-exposure matrix for pesticides in agriculture.

Results Compared with nonapplicators, current applicators reported significantly more dizziness, sleepiness, and headache and had a higher overall neurological symptom score. This association remained statistically significant after multiple logistic regression analyses controlling for a range of confounders and effect modifiers [odds ratio (OR) 2.25, for current applicators having high neurological score, 95\% confidence interval (95\% CI) 1.15-4.39]. The average lifetime intensity of organophosphate exposure was nonsignificantly associated with both neurological (OR 1.98, 95\% CI 0.49-7.94) and "dummy" symptoms (OR 2.37, 95\% CI 0.54-10.35). Previous pesticide poisoning was significantly associated with the neurological scores (OR 4.08, 95\% CI 1.48-11.22) but not with the "dummy" symptoms. Vibration sense outcomes were associated with age and height, but not with the organophosphate exposure measures. In the multiple linear regression modeling for tremor intensity in the dominant hand, recent organophosphate exposure in the past 10 days was a significant predictor (partial correlation coefficient $=0.04$ ), but none of the long-term organophosphate exposure measures were significant.

Conclusions Strong evidence was found for an association between symptom outcomes and past organophosphate poisoning and between symptom outcomes and current spray activity. In contrast to symptoms, there was no association between either past poisoning or current spray activity and vibration sense or tremor outcome. Longterm organophosphate exposure did not appear to predict symptoms, vibration sense, or tremor outcome.
\end{abstract}

Key terms farm workers, long-term exposure, organophosphates.

The use of pesticides and related chemicals in farming and public health programs has increased markedly over the past few decades $(1,2)$, particularly in the less developed countries, including South Africa (3). Research on adverse health effects associated with occupational exposure to agrichemicals has usually focused on acute, severe outcomes, such as hospital admissions (4), selfreported poisoning (5), case reports involving fatalities (6), epidemic outbreaks (7), and surveys of statutory notification $(8-10)$. Studies that have investigated subacute or chronic effects of agrichemical exposures have frequently concerned environmental settings $(11,12)$ or groups of workers involved in agrichemical production (13-15) and have less commonly investigated farm workers $(11,16,17)$.

Particular attention has been focused on the potential neurotoxic effects of exposure to agrichemicals, particularly organophosphates (18). Of note, however, is that most studies of chronic neurological outcomes have been carried out among survivors of acute poisoning $(16,19-$ 21), typically from high-dose acute exposure. Long-term low-grade exposure is increasingly being suspected of

1 Occupational and Environmental Health Research Unit, Department of Community Health, University of Cape Town, Observatory, South Africa.

2 Health Psychology Unit, University of South Africa, Johannesburg, South Africa.

3 Department of Statistical Sciences, University of Cape Town, Private Bag Rondebosch, South Africa.

Reprint requests to: Dr L London, Occupational and Environmental Health Research Unit, Department of Community Health, University of Cape Town, Anzio Road, Observatory, 7925, South Africa. [e-mail: 11@anat.uct.ac.za] 
having effects similar to the chronic effects caused by acute exposure $(18,22,23)$. However, poor exposure assessment in studies of long-term exposure has frequently resulted in exposure misclassification (24) with a resultant decrease in study power, and studies of long-term exposures have tended not to take into account the effects of past poisoning or acute exposure.

The chronic health effects arising from long-term low-dose exposure are therefore relatively unexplored (25), particularly in less developed countries (18). Furthermore, the high levels of alcohol intake, malnutrition, and poverty that characterize living conditions on most South African farms (26) may play an important exacerbating or confounding role in possible chronic chemicalrelated morbidity. Some evidence for the presence of an undiagnosed reservoir of chronic neurotoxic disease related to pesticide exposure was found in a pilot study in the apple farming industry in Western Cape in 1992; it demonstrated impaired vibration sense among pesticide applicators when they were compared with a group of packstore employees (unpublished report: Manjra S, London L, Myers JE. "Diminished Vibration Sensation and Chronic Agrichemical Exposure in Farm Workers").

In order to confirm these preliminary findings and to characterize fully the entire spectrum of morbidity and mortality associated with agrichemical exposure, a study was undertaken in 1993 on the prevalence of selected neurological and neurobehavioral disorders among farm workers with long-term exposure to agrichemicals in the rural Western Cape. The study aimed at investigating the hypothesis that, independent of acute exposure or past poisoning, long-term organophosphate exposures among farm workers was associated with the development of selected adverse nervous system outcomes. This paper reports the results of analyses of neurological symptoms, vibration sense, and tremor outcomes. Related papers report on the validity and reproducibility of exposure estimates (unpublished report: London L, Myers JE. "The Use of a Crop- and Job-specific Exposure Matrix for Retrospective Assessment of Long-term Exposure in Studies of Chronic Neurotoxic Effects of Agrichemicals") and on exposure-effect relationships for neurobehavioral test outcomes based on the World Health Organization Neurobehavioral Core Test Battery (WHO-NCTB) and on an information processing test battery (IP tests) (27).

\section{Subjects and methods}

A cross-sectional analytical survey was performed on 113 deciduous fruit farms belonging to 3 large coopera- tives in an intensive farming region of the rural Western Cape Province in South Africa. The study took place from January to March 1993 during the peak agrichemical spraying season. The deciduous fruit industry was chosen for its high agrichemical use and its role as a leading employer in the region (28).

All the applicators from participating farms were included in the study, as well as 1 nonspraying referent, group-matched for age and educational status, for every 2 applicators selected (table 1). The ratio of applicators to nonapplicators was chosen to generate a sufficient gradient for long-term exposure in the sample, while matching was required to control for important potential confounders for the neurobehavioral assessment (table 2). Nonapplicators were typically involved in orchard work, mechanical maintenance, and gardening activities on farms. Power calculations based on data reported from the WHO neurotoxicology program (29-32), using an alpha of 0.05 and taking the least departure of interest to be $10 \%$, suggested that a sample size of 240 would achieve a beta of 0.9 .

Because of cultural concerns related to the validity of the neurobehavioral assessment tools (33), the study subjects were restricted to male colored ${ }^{4}$ farm workers. Workers with any evidence of vitamin deficiency, encephalopathy of known origin, a history of long-term administration of psychotropic medication, or previous injury resulting in deformity or other abnormality of the lower limbs interfering with peripheral sensation were excluded from the study.

A total of 164 applicators and 83 nonapplicators representing $68 \%$ of the eligible workers from $65 \%$ of the eligible farms participated in the study. Nonresponding farms tended to be further away (more than an hour's travel from the nearest rural town) and were more likely to be less than 25 ha in size. The mean age of the subjects was 36.9 (SD 10.0) years and the mean educational level

Table 1. Demographic characteristics of the study sample.

\begin{tabular}{|c|c|c|c|c|c|}
\hline \multirow[t]{2}{*}{ Group } & \multicolumn{2}{|c|}{ Age (years) } & \multicolumn{2}{|c|}{$\begin{array}{c}\text { Schooling } \\
\text { (completed } \\
\text { years) }\end{array}$} & \multirow[t]{2}{*}{$\begin{array}{c}\text { Illiteracy } \\
(\%)^{\mathrm{a}}\end{array}$} \\
\hline & Median & Range & Median & Range & \\
\hline $\begin{array}{l}\text { Applicators } \\
(N=164)\end{array}$ & 34 & $30-43$ & 6 & $0-10$ & 21 \\
\hline $\begin{array}{l}\text { Nonapplicators } \\
(\mathrm{N}=83)\end{array}$ & 33 & $30-42$ & 6 & $0-12$ & 22 \\
\hline $\begin{array}{l}\text { All workers } \\
(\mathrm{N}=247)\end{array}$ & 34 & $20-72$ & 6 & $0-12$ & 21 \\
\hline
\end{tabular}

4 Colored people form both the bulk of the work force in the Western Cape and a cultural group distinct from black South Africans previously classified as "Africans". Use of the terms by the authors does not indicate support for the policies that established these distinctions but rather recognizes cultural differences in a race-cleaved society. 
Table 2. Characteristics important for the neurobehavioral assessment of the study sample. ${ }^{a}\left(\mathrm{CAGE}^{\mathrm{b}}=\right.$ cutting down, angered by friends, guilty,

\begin{tabular}{|c|c|c|c|c|c|c|c|c|c|c|c|}
\hline \multirow[t]{3}{*}{ Group } & \multicolumn{11}{|c|}{ Alcohol intake and smoking } \\
\hline & \multicolumn{3}{|c|}{ Alcohol use $(\%)$} & \multicolumn{2}{|c|}{$\begin{array}{l}\text { Cumulative lifetime } \\
\text { kilograms of alcohol }\end{array}$} & \multicolumn{2}{|c|}{ CAGEa score } & \multicolumn{2}{|c|}{ MASTa score } & \multicolumn{2}{|c|}{$\mathrm{GGT}^{\mathrm{b}}$} \\
\hline & $\begin{array}{l}\text { Current } \\
(\%)\end{array}$ & $\begin{array}{l}\text { Past } \\
(\%)\end{array}$ & $\begin{array}{l}\text { Never } \\
(\%)\end{array}$ & Median & Range & Median & Range & Median & Range & Median & Range \\
\hline $\begin{array}{l}\text { Applicators }(N=164) \\
\text { Nonapplicators }(N=83)\end{array}$ & $\begin{array}{l}67 \\
69\end{array}$ & $\begin{array}{l}29 \\
27\end{array}$ & $\begin{array}{l}4 \\
5\end{array}$ & $\begin{array}{l}179 \\
156\end{array}$ & $\begin{array}{l}0-1000 \\
0-684\end{array}$ & $\begin{array}{l}3 \\
3\end{array}$ & $\begin{array}{l}0-4 \\
0-4\end{array}$ & $\begin{array}{l}6 \\
7\end{array}$ & $\begin{array}{l}0-27 \\
0-20\end{array}$ & $\begin{array}{l}19 \\
16\end{array}$ & $\begin{array}{l}5-121 \\
7-124\end{array}$ \\
\hline All workers $(N=247)$ & 68 & 28 & 5 & 170 & $0-1000$ & 3 & $0-4$ & 6 & $0-27$ & 18 & $5-124$ \\
\hline
\end{tabular}

a Incomplete medial history for 9 subjects -3 applicators and 6 nonapplicators.

b Mayfield et al (39).

c Setzer (41)

achieved was 5.1 (SD 2.9) years of schooling. There were 52 subjects $(21 \%)$ unable to sign their names in giving consent for the study, suggesting substantial illiteracy. According to a modification of UNESCO criteria [less than 6 years of completed schooling (34)], approximately $44 \%$ of the subjects would be considered illiterate. Nonnumeracy was found for 9 subjects $(4 \%)$. The differences in age and education between the referents and applicators were small (table 1 ).

Table 3 summarizes the exposure variables, potential confounders, and effect modifiers and outcome variables measured in the study and the methods by which these variables were measured. Different observers were involved in the exposure and outcome ascertainment. Measurement of exposure was therefore blind to outcome status, and vice versa. Dedicated observers and equipment were used for the entire duration of the study.

\section{Exposure assessment}

Long-term organophosphate exposure was determined using a job-exposure matrix for agricultural chemical exposure developed specifically for this study (unpublished report: London L, Myers JE. "The Use of a Cropand Job-Specific Exposure Matrix for Retrospective Assessment of Long-term Exposure in Studies of Chronic Neurotoxic Effects of Agrichemicals"). The job-exposure matrix was structured to take into account reported direct exposures (application, mixing), as well as indirect exposures (field contacts, spray drift, etc) using weightings for diverse job activities derived from industrial hygiene assessments and expert opinions. For every lifetime job, weighted exposure days from all routes were summed and further weighted for crop sector according to secondary industry data. Exposure was therefore characterized as a continuous variable (cumulative and average intensity of exposure was alternately used in the analyses) rather than as a dichotomous (exposed versus unexposed) variable.

The exposure variables derived from the job-exposure matrix are summarized in table 4 . The median lifetime days spent spraying organophosphates from a mist blower was 20.8 (range $0-1651$ ) and the median cumulative organophosphate exposure days from all farm activities was 176 (range $0-4670$ ). The weighting of organophosphate usage by crop sector gave a median cumulative organophosphate exposure of 2.05 (range 0 $63.71) \mathrm{kg}$ and a median lifetime intensity of (log transformed) organophosphate/year of exposure of 0.12 (range $0-1.09) \mathrm{kg}$.

Recent occupational exposure to organophosphates was assessed by questionnaire, from farm records, and by measurement of plasma cholinesterase as a biological marker of recent exposure. Forty-seven percent of the applicators reported that they had applied organophosphates in the preceding 10 days before examination and $22 \%$ had applied organophosphates on the morning of or the morning before their examination. Because of poor agreement between the estimate of acute exposure based on farmer records and that reported by the subjects (kappa 0.19 ), plasma cholinesterase was used as the primary marker of recent worker exposure in the subsequent analyses rather than any of the record or history data. Plasma cholinesterase has the advantage of being an integrated measure of the biological effect of organophosphates on the human body and thus more closely allows control for confounding by acute exposure of the effects of long-term exposure on neurological and neurobehavioral function. Plasma cholinesterase was measured at the Department of Chemical Pathology of the Groote Schuur Hospital, Cape Town, using butyrylthiocholine as a substrate according to standard methods (36), and excellent precision of these analyses have been reported elsewhere (37). There were a few exposures to nonfarming, potentially neurotoxic chemicals $(\mathrm{N}=6)$, and these exposures were treated as dichotomous (present or absent) in the subsequent analysis.

Nonoccupational exposure was measured according to history based on the use of pesticides at home, the use of pesticide containers for domestic purposes, gardening activities, and lifetime residential exposure to possible spray drift. The subjects reported that they had spent an average of 32.3 (SD 11.1) years as a resident on a farm. 
eye opener; $M_{A S T}{ }^{\circ}=$ Michigan alcoholism screening test; $G G T=$ serum gamma glutamyl transpeptidase)

\begin{tabular}{|c|c|c|c|c|c|c|c|c|}
\hline & & & \multicolumn{6}{|c|}{ Medical History (\%) } \\
\hline \multicolumn{3}{|c|}{$\begin{array}{c}\text { Smoking } \\
\text { history (\%) }\end{array}$} & \multirow[t]{2}{*}{$\begin{array}{c}\text { Epilepsy } \\
(\%)\end{array}$} & \multirow[t]{2}{*}{$\begin{array}{c}\text { Diabetes } \\
(\%)\end{array}$} & \multirow[t]{2}{*}{$\begin{array}{l}\text { Any brain } \\
\text { injury (\%) }\end{array}$} & \multirow{2}{*}{$\begin{array}{c}\text { Brain injury } \\
\text { causing loss } \\
\text { of consciousness } \\
\text { for }>1 \text { hour }(\%)\end{array}$} & \multirow{2}{*}{$\begin{array}{l}\text { On current } \\
\text { medication } \\
(\%)\end{array}$} & \multirow{2}{*}{$\begin{array}{c}\text { Impaired } \\
\text { visual acuity } \\
(\%)\end{array}$} \\
\hline $\begin{array}{c}\text { Current } \\
(\%)\end{array}$ & $\begin{array}{c}\text { Past } \\
(\%)\end{array}$ & $\begin{array}{c}\text { Never } \\
(\%)\end{array}$ & & & & & & \\
\hline $\begin{array}{l}80 \\
83\end{array}$ & $\begin{array}{l}10 \\
13\end{array}$ & $\begin{array}{r}10 \\
4\end{array}$ & $\begin{array}{l}2 \\
3\end{array}$ & $\begin{array}{l}1 \\
0\end{array}$ & $\begin{array}{l}71 \\
70\end{array}$ & $\begin{array}{l}34 \\
30\end{array}$ & $\begin{array}{l}11 \\
12\end{array}$ & $\begin{array}{l}5 \\
5\end{array}$ \\
\hline 81 & 11 & 8 & 2 & 1 & 70 & 33 & 11 & 5 \\
\hline
\end{tabular}

Over $85 \%$ of these years were reported as a resident on a farm where tractor or aerial spraying of agrichemicals had taken place, and for $34 \%$ of these years spraying was reported to have taken place within $10 \mathrm{~m}$ of their residence.

\section{Potential confounders and effect modifiers}

Among the wide range of potential confounders and effect modifiers measured (table 3), the most important included age, height, education level, numeracy, visual acuity, and alcohol intake. Levels below the clinical "normal range" for hemoglobin $(13.5-17.0 \mathrm{~g} / \mathrm{dl})$ and albumen $(35-50 \mathrm{~g} / \mathrm{dl})$ were found for $17 \%$ and $2 \%$ of the subjects, respectively. The mean height of the subjects was 165.0 (SD 5.8) $\mathrm{cm}$. Previous brain injuries were common in the sample, and there was a history of 303 brain injuries causing loss of consciousness lasting a few seconds or longer for 169 subjects (70\%). Eighty-two subjects (34\%) experienced two or more episodes of loss of consciousness as a result of brain injury, and for 79 subjects (33\%) the loss of consciousness was reported as lasting an hour or longer (table 2).

Detailed attention was given to alcohol consumption, given its known neurotoxic effects and the historically high levels of alcohol intake among farm workers in South Africa $(26,38)$. The latter included detailed questioning on usual drinking pattern by day of the week, most recent pattern, and perceptions of normal and abnormal drinking. All the measures were converted to grams of pure alcohol. The subjects were also asked a set of questions derived from 2 widely used inventories of alcohol intake, the CAGE questionnaire (39) and the MAST interview (40). Serum gamma glutamyl transferase was measured as a biological effect marker for short-term alcohol consumption.

The average cumulative lifetime consumption of alcohol (pure alcohol equivalents) was 217 (SD 204) kg with a range from 0 to over $1000 \mathrm{~kg}$ (table 2). Less than $5 \%$ reported having never consumed alcohol. Using the clinical range quoted by the Groote Schuur Hospital Chemical Pathology Laboratory $(0-40 \mathrm{U} / 1), 11 \%$ of the sample exhibited elevated levels of gamma glutamyl transpeptidase. Scoring on the CAGE and MAST questionnaires suggested that $87 \%$ and $65 \%$, respectively, of the sample would be defined as alcoholic.

Past occupational poisoning with pesticides was reported by 22 subjects (9\%), of whom $15(6 \%)$ reported time off work or consultation with a doctor. In none of these cases was the chemical responsible identified. Past exposure to chemical fumes or vapors resulting in dizziness or collapse was also reported by 28 subjects $(12 \%$, $\mathrm{N}=240$ ). The agreement between these 2 reported sources of poisoning was poor (Spearman's $r$ 0.076), and the latter cases of intoxication may have included cases of mild or nonoccupational pesticide poisoning not reported in the occupational history. A composite past poisoning variable (either specific pesticide intoxication or reported fume intoxication) was used as an alternative to each separate variable in further multivariate analyses for various neurotoxic outcomes.

\section{Outcomes}

The outcomes measured included neurological symptoms, vibration sense, motor tremor, and the results of a neurobehavioral test battery. A set of 14 symptoms, including 12 presumptively neurological and 2 "dummy" symptoms, was derived from a previous checklist (41). All the reported symptoms were qualified by an additional question on chronicity, defined as to whether the symptom had been present for the past 3 months. A score was derived for the neurological (maximum 12) and "dummy" (maximum 2) symptoms.

Vibration sense was measured with the Vibratron II (Sensortek Inc, Clifton, New Jersey, United States) in the large toe of the nondominant leg, using the method of limits (42). To maximize reliability and validity, application was performed by the same observer using a single apparatus throughout the study. The apparatus was calibrated against an external accelerometer at the start and end of each set of tests. In addition, a wooden box was used to support the subject's foot during the test procedure to reduce strain and improve the standardization of 
Table 3. Measured variables. $($ WHO NCTB $=$ World Health Organization Neurobehavioral Core Test Battery, $I P=$ Information Processing test, $\mathrm{PPE}=$ personal protective equipment)

\begin{tabular}{|c|c|}
\hline Variables & Instrument \\
\hline \multicolumn{2}{|l|}{ Exposure variables } \\
\hline \multicolumn{2}{|l|}{$\begin{array}{l}\text { Nonoccupational agrichemical } \\
\text { exposure }\end{array}$} \\
\hline $\begin{array}{l}\text { Domestic use } \\
\text { Lifetime environmental }\end{array}$ & Interview \\
\hline & Interview \\
\hline member & Interview \\
\hline \multicolumn{2}{|l|}{$\begin{array}{l}\text { Occupational exposure to } \\
\text { organophosphates }\end{array}$} \\
\hline $\begin{array}{l}\text { Cumulative exposure } \\
\text { Average exposure intensity } \\
\text { Peak lifetime exposure }\end{array}$ & Interview and modeling \\
\hline Acute exposure & $\begin{array}{l}\text { Interview, blood for plasma an } \\
\text { erythrocyte cholinesterase } \\
\text { estimation } \\
\text { Farmer questionnaire } \\
\text { Farm records }\end{array}$ \\
\hline \multicolumn{2}{|l|}{ Outcome variables } \\
\hline Neurological symptoms & Interview \\
\hline Impaired vibration sense & $\begin{array}{l}\text { Vibration Ila } \\
\text { Tuning for extinction time }\end{array}$ \\
\hline Motor tremor & La Fayette testing device ${ }^{b}$ \\
\hline Neurobehavioral & $\begin{array}{l}\text { WHO NCTB } \\
\text { IP batteryc }\end{array}$ \\
\hline \multicolumn{2}{|l|}{$\begin{array}{l}\text { Potential confounders and effect } \\
\text { modifiers }\end{array}$} \\
\hline Smoking & Interview \\
\hline Alcohol intake & $\begin{array}{l}\text { Interview } \\
\text { Serum gamma glutamyl } \\
\text { transpeptidase }\end{array}$ \\
\hline Nutritional status & Serum albumen \\
\hline Dagga (cannabis) use & Interview \\
\hline $\begin{array}{l}\text { Previous brain injury or loss } \\
\text { of consciousness }\end{array}$ & \\
\hline $\begin{array}{l}\text { of consciousness } \\
\text { Previous pesticide poisoning }\end{array}$ & $\begin{array}{l}\text { Interview } \\
\text { Interview }\end{array}$ \\
\hline $\begin{array}{l}\text { Previous pesticide poisoning } \\
\text { Education }\end{array}$ & $\begin{array}{l}\text { Mnerview } \\
\text { Interview }\end{array}$ \\
\hline Parental occupation & Interview \\
\hline video games & Interview \\
\hline Numeracy & Examination \\
\hline Age & Interview \\
\hline Height & Examination \\
\hline $\begin{array}{l}\text { Visual acuity } \\
\text { Occupational exposure } \\
\text { to nonpesticide }\end{array}$ & Examination \\
\hline neurotoxins & Interview \\
\hline Knowledge, attitude and practice & \\
\hline $\begin{array}{l}\text { with regard to PPE } \\
\text { Nonoccupational exposure to }\end{array}$ & Interview \\
\hline $\begin{array}{l}\text { nonpesticide neurotoxins } \\
\text { Medical history of neurological }\end{array}$ & Interview \\
\hline or related disorders & Interview \\
\hline Use of medication & Interview \\
\hline
\end{tabular}

a Vibratron II (Sensortek Inc, Clifton, NJ, 1989) was used to measure the vibrotactile thresholds.

b The tremor testing device measures the subjects' static and dynamic steadiness.

c Neurobehavioral test battery based on an information processing model of cognitive psychology (36)

the administration. Vibration sense measurement was supplemented by the use of a $256-\mathrm{Hz}$ frequency tuning fork to estimate extinction time. The extinction time was measured in seconds from the release of the tuning fork arms from a slot in a polyvinyl cylinder until the subject reported that he could no longer feel the vibration against his malleolus. An average of the last 2 of 3 readings was used as the extinction time.

Static motor steadiness and dynamic steadiness were also tested in this study. For the testing of the former, the subject held a stylus pen inside holes in a metal plate of decreasing diameter for 15 seconds at a time without touching the sides of the hole. For the latter, the subject negotiated a maze mounted on a board at an angle of $45^{\circ} \mathrm{C}$ without touching the sides of the maze. Contact with the side of the holes or the maze registered a count. Scores were derived for both the dominant and nondominant hands for (i) the number of holes the subject achieved, (ii) tremor intensity as measured by the average of counts per hole weighted by the inverse of the number of holes achieved, (iii) time needed to complete the maze (average of 2 trials), and (iv) counts registered on maze trials (average of 2 trials). Data on the latter 2 measures have not been reported in this paper as they did not differ substantially from the results obtained using tremor count and tremor intensity.

\section{Statistical analyses}

Multiple linear and logistic analyses were used to evaluate the relationship between long-term occupational exposure to organophosphates and the various neurological and neurobehavioral outcomes after control for expected confounders. Forced modeling was used in every case, and the variables included in the model consisted of a set of "a priori" variables and any additional variables found to be associated with the outcome under investigation in a bivariate analysis. The a priori variables included age, education, past history of pesticide poisoning, lifetime alcohol consumption, recent organophosphate exposure, nonoccupational residential exposure, and long-term occupational organophosphate exposure. For the last variable, the cumulative or average lifetime intensity of occupational organophosphate exposure was used alternately in the analyses. The vibration sense outcomes also included height as an a priori variable in the model. Both recent occupational exposure and a past history of pesticide poisoning were treated as potential confounders in the analyses. Outcome variables that could not be transformed to normality (tremor score and symptom scores) were dichotomized around their medians to allow for multiple logistic regression analyses. All the analyses were carried out with SAS software (43).

\section{Repeatability}

To assess data repeatability, a $10 \%$ random subsample (29 subjects) underwent repeat interviews 3 months after the survey. For the categorical variables, satisfactory kappa estimates (44) (exceeding 0.4) were obtained for history of previous head injury (0.66), past loss of consciousness $(0.43)$, and past pesticide poisoning $(0.65)$. 
Table 4. Exposure parameters of the deciduous fruit farm workers.

\begin{tabular}{|c|c|c|c|c|c|c|c|c|c|c|c|}
\hline \multirow[t]{2}{*}{ Group } & \multicolumn{2}{|c|}{$\begin{array}{l}\text { Lifetime days } \\
\text { driving mist } \\
\text { blower }\end{array}$} & \multicolumn{2}{|c|}{$\begin{array}{l}\text { Lifetime days } \\
\text { in all exposed } \\
\text { job activities }\end{array}$} & \multicolumn{2}{|c|}{$\begin{array}{l}\text { Cumulative } \\
\text { kilograms of } \\
\text { organophosphate } \\
\text { exposure }\end{array}$} & \multicolumn{2}{|c|}{$\begin{array}{l}\text { Average intensity } \\
\text { of lifetime } \\
\text { organophosphate } \\
\text { exposure }^{c}\end{array}$} & \multirow{2}{*}{$\begin{array}{c}\text { Persons } \\
\text { reporting } \\
\text { organo- } \\
\text { phosphate } \\
\text { exposure in } \\
\text { preceding } \\
10 \text { days }(\%)\end{array}$} & \multicolumn{2}{|c|}{$\begin{array}{c}\text { Plasma } \\
\text { cholinesterase } \\
\text { (IU/I) }\end{array}$} \\
\hline & Median & Range & Median & Range & Median & Range & Median & Range & & Mean & SD \\
\hline $\begin{array}{l}\text { Applicators } \\
(N=164)\end{array}$ & 165 & $0-4644$ & 318 & $0-4670$ & 3.90 & $0.01-63.71$ & 0.17 & $0.00-1.08$ & 47 & 6416 & 1251 \\
\hline $\begin{array}{l}\text { Nonapplicators } \\
(\mathrm{N}=83)\end{array}$ & 0 & $0-2064$ & 78 & $0-2122$ & 1.03 & $0.00-28.95$ & 0.05 & $0.00-0.86$ & 29 & 6240 & 1194 \\
\hline $\begin{array}{l}\text { All workers } \\
(N=247)\end{array}$ & 21 & $0-4644$ & 176 & $0-4670$ & 2.05 & $0.00-63.71$ & 0.12 & $0.00-1.08$ & 42 & 6537 & 1232 \\
\hline
\end{tabular}

a Job days weighted for estimate of exposure in each activity.

b Cumulative exposure expressed in kilograms of organophosphate weighted for job activity and crop sector.

- Average intensity of exposure expressed in kilograms of organophosphate/year weighted for job activity and crop sector.

For the continuous variables, the agreement ranged from excellent (Pearson's $r>0.9$ ) for demographic variables such as age and schooling to moderately good [Spearman's correlations ( $r)$ ] for measures such as lifetime alcohol consumption $(r=0.69)$, CAGE score $(r=0.75)$, MAST score $(r=0.64)$, number of head injuries reported $(\mathrm{r}=0.77)$, and measures of long-term workplace organophosphate exposure (generally of the order of 0.6 ).

\section{Results}

\section{Neurological symptom outcomes}

Tables 5 and 6 present the prevalence of symptoms (both current and prolonged for the past 3 months) and symptom scores among the work force, stratified by current applicator status. The most common symptoms reported include headache, sleepiness, and tiredness. Persistent drowsiness was the most prevalent of the symptoms present for 3 months. The "dummy" symptom of earache was relatively uncommon though chest pain was as widely reported as the neurotoxic symptoms. Reporting of either group of symptoms was moderately correlated.
(Spearman's correlation coefficient between symptom scores for neurological and dummy symptoms was 0.42 , $\mathrm{P}=0.0001$.)

Current applicators had increased reporting of all symptoms (except for disturbance of gait for 3 months and earache). This increase was statistically significant $\left(\chi^{2}\right.$ test, $\left.P<0.05\right)$ for dizziness, headache, sleepiness (table 5), and overall score for neurological symptoms (table 6).

Table 7 presents the odds ratios and $95 \%$ confidence intervals for the significant predictors of the symptom scores. The symptom scores were dichotomized as high versus low for neurological ( 2 or more versus less than 2 ) and for "dummy" ( 1 or more versus 0 ) symptoms. Similarly, plasma cholinesterase and lifetime alcohol consumption were dichotomized around the median for purposes of the analyses. Both forced and stepwise multiple logistic regression analyses (criterion for entry being improvement in model fit at $\mathrm{P}<0.15$ ) were performed, and the results were broadly similar, as were results for the analyses using measures of average intensity of organophosphate exposure rather than cumulative lifetime exposure. Only the results of the forced modeling are presented in table 7.

Table 5. Prevalence (\%) of neurological and other symptoms. ( $C=$ current, $\mathrm{P} 3 \mathrm{M}=$ past 3 months)

\begin{tabular}{|c|c|c|c|c|c|c|c|c|c|c|c|c|c|c|c|c|c|c|c|c|c|c|c|c|c|c|c|}
\hline \multirow[t]{3}{*}{ Group } & \multicolumn{27}{|c|}{ Symptom (\%) } \\
\hline & $\begin{array}{l}\text { Stomach } \\
\text { pain }\end{array}$ & \multicolumn{2}{|c|}{ Nausea } & \multicolumn{2}{|c|}{$\begin{array}{l}\text { Dizzi- } \\
\text { ness* }\end{array}$} & \multicolumn{2}{|c|}{$\begin{array}{c}\text { Gait } \\
\text { dis } \\
\text { turbed } \\
\end{array}$} & \multicolumn{2}{|c|}{$\begin{array}{l}\text { Numb- } \\
\text { ness } \\
\text { limbs }\end{array}$} & \multicolumn{2}{|c|}{$\begin{array}{l}\text { Paras- } \\
\text { thesia }\end{array}$} & \multicolumn{2}{|c|}{ Earache } & \multicolumn{2}{|c|}{$\begin{array}{c}\text { Lame- } \\
\text { ness } \\
\text { limbs }\end{array}$} & \multicolumn{2}{|c|}{$\begin{array}{l}\text { Pain in } \\
\text { limbs }\end{array}$} & \multicolumn{2}{|c|}{$\begin{array}{l}\text { Rinor- } \\
\text { rhoea }\end{array}$} & \multicolumn{2}{|c|}{$\begin{array}{l}\text { Head- } \\
\text { ache* }\end{array}$} & \multicolumn{2}{|c|}{$\begin{array}{l}\text { Sleepi- } \\
\text { ness* }\end{array}$} & \multicolumn{2}{|c|}{$\begin{array}{l}\text { Chest } \\
\text { pain }\end{array}$} & \multicolumn{2}{|c|}{ Tiredness } \\
\hline & C P3M & CP & $3 \mathrm{M}$ & $C P$ & $3 \mathrm{M}$ & C & P3M & & P3M & $C F$ & P3M & & P3M & $G F$ & P3M & C & P3M & $G$ & P3M & $C P$ & P3M & $\mathrm{C}$ & P3M & $C F$ & P3M & $C F$ & P3M \\
\hline $\begin{array}{l}\text { Applicators } \\
(N=164)\end{array}$ & 24 & 20 & 5 & 35 & 8 & 6 & 1 & 10 & 4 & 17 & 5 & 5 & 2 & 20 & 6 & 20 & 7 & 23 & 6 & 45 & 11 & 43 & 18 & 21 & 7 & 37 & 13 \\
\hline $\begin{array}{l}\text { Nonapplicators } \\
(N=83)\end{array}$ & 16 & 13 & 1 & 21 & 4 & 7 & 2 & 2 & 0 & 15 & 2 & 10 & 1 & 16 & 1 & 19 & 4 & 16 & 0 & 25 & 4 & 23 & 5 & 16 & 5 & 28 & 7 \\
\hline $\begin{array}{l}\text { All workers } \\
(\mathrm{N}=247)\end{array}$ & 21 & 17 & 4 & 30 & 7 & 6 & 2 & 7 & 2 & 16 & 4 & 7 & 2 & 18 & 4 & 19 & 6 & 21 & 4 & 39 & 9 & 36 & 13 & 19 & 6 & 34 & 11 \\
\hline
\end{tabular}

$* P<0.05$, chi-square for difference in proportion of those reporting symptoms between the applicators and nonapplicators. 
Table 6. Biochemical, clinical, and neurological test results of the deciduous fruit farm workers.

\begin{tabular}{|c|c|c|c|c|c|c|c|c|c|c|c|c|c|c|c|c|c|}
\hline \multirow[t]{3}{*}{ Group } & \multirow{3}{*}{$\begin{array}{l}\text { Preva- } \\
\text { lence of } \\
\text { clinical } \\
\text { deficit } \\
(\%)\end{array}$} & \multicolumn{4}{|c|}{ Score } & \multirow{2}{*}{\multicolumn{2}{|c|}{$\begin{array}{l}\text { Vibration } \\
\text { thresholda }\end{array}$}} & \multirow{2}{*}{\multicolumn{2}{|c|}{$\begin{array}{l}\text { Tuning fork } \\
\text { extinction } \\
\text { time (s) }\end{array}$}} & \multicolumn{4}{|c|}{ Tremor scorec } & \multicolumn{4}{|c|}{ Tremor intensity ${ }^{d}$} \\
\hline & & \multirow{2}{*}{\multicolumn{2}{|c|}{$\begin{array}{l}\text { Neurological } \\
\text { symptoms }^{* *}\end{array}$}} & \multirow{2}{*}{\multicolumn{2}{|c|}{$\begin{array}{c}\text { "Dummy" } \\
\text { symptoms } \\
\text { Mean Range }\end{array}$}} & & & & & \multicolumn{2}{|c|}{$\begin{array}{l}\text { Dominant } \\
\text { hand }\end{array}$} & \multicolumn{2}{|c|}{$\begin{array}{l}\text { Nondominant* } \\
\text { hand }\end{array}$} & \multicolumn{2}{|c|}{$\begin{array}{l}\text { Dominant } \\
\text { hand }\end{array}$} & \multicolumn{2}{|c|}{$\begin{array}{l}\text { Nondominant } \\
\text { hand }\end{array}$} \\
\hline & & & & & & Mean & SD & Mean & $\mathrm{SD}$ & Mean & SD & Mean & SD & Mean & $\mathrm{SD}$ & Mean & SD \\
\hline $\begin{array}{l}\text { Applicators } \\
(N=164)\end{array}$ & 3 & 2 & $0-12$ & 0 & $0-2$ & 7.80 & 1.11 & 12.8 & 3.4 & 5.7 & 0.9 & 5.5 & 0.9 & 0.36 & 0.30 & 0.37 & 0.33 \\
\hline $\begin{array}{l}\text { Nonapplicators } \\
(\mathrm{N}=83)\end{array}$ & 0 & 1 & $0-12$ & 0 & $0-2$ & 7.71 & 1.18 & 12.6 & 3.2 & 5.5 & 0.9 & 5.2 & 1.0 & 0.42 & 0.39 & 0.44 & 0.52 \\
\hline All workers $(\mathrm{N}:=247)$ & 2 & 2 & $0-12$ & 0 & $0-2$ & 7.77 & 1.13 & 12.7 & 3.3 & 5.7 & 0.9 & 5.4 & 1.0 & 0.38 & 0.34 & 0.39 & 0.41 \\
\hline
\end{tabular}

average of last 8 of 9 trials per subject. Vibratron units were log transformed.

- Average of last 2 of 3 trials per subject.

c Total number of holes of descending size order successfully reached.

a Cumulative counts excluding counts of last hole divided by number of holes achieved minus 1

${ }^{*} P<0.05,{ }^{* *} P<0.005$, Wilcoxon 2-sample test.

Table 7. Significant predictors of symptom scores for the deciduous fruit farm workers according to the multiple logistic regression $\left(\mathrm{N}=221^{\mathrm{a}}\right) .^{\mathrm{b}}(95 \% \mathrm{Cl}=95 \%$ confidence interval; $\mathrm{CAGE}^{\mathrm{b}}=$ cutting down, angered by friends, guilty, eye opener)

\begin{tabular}{l}
\hline Significant predictors \\
\hline High scorec for \\
neurological symptoms \\
Past pesticide poisoning \\
Current pesticide applicator \\
Number of past head injuries \\
causing loss of consciousness \\
CAGE score \\
High scorec for "dummy" symptoms. \\
Number of past head \\
injuries causing loss \\
of consciousness \\
\hline
\end{tabular}

Both current work as a pesticide applicator and previous poisoning by pesticides were significantly related to the reporting of neurological symptoms, but not to the "dummy" symptoms, as was a higher score on the CAGE questionnaire for alcoholism. The OR for the association between past poisoning and the "dummy" symptoms was 1.19 (95\% CI $0.49-2.91)$. The number of head injuries resulting in loss of consciousness was significantly related to both groups of symptoms - for each past head injury causing any degree of loss of consciousness, the subjects were about $40 \%$ to $55 \%$ more likely to score high on either group of symptoms. There were no significant relationships of either group of symptom outcomes to long-term organophosphate exposure, although the average lifetime exposure to organophosphates was nonsignificantly related to an increase in both the reported neurological symptoms and the "dummy" symptoms (OR $1.98,95 \%$ CI $0.49-7.94$, and OR $2.37,95 \%$ CI $0.54-$ 10.35 , respectively).

\section{Clinical findings}

The neurological examination identified 1 subject with a frank sensorimotor distal neuropathy and 4 subjects with lesser degrees of clinical impairment of pinprick discrimination. All 5 affected subjects were current applicators although the difference between the applicators and the nonapplicators was not statistically significant (Fisher's exact test, $P=0.13$ ). The subjects with evidence of clinical deficits were older, were more poorly educated, had a higher cumulative and average intensity of occupational exposure, and had a greater lifetime alcohol consumption, although none of these differences was statistically significant $(P>0.05$, Wilcoxon comparison of medians). Multiple logistic regression analysis with clinical deficit as the outcome did not identify any significant predictors.

\section{Outcome measures for vibration sense}

There were no significant differences between current applicators and the referents for the mean log vibratron units, nor for mean tuning fork extinction time (table 6). Multiple linear regression modeling was able to explain only moderately the variance in the vibration sense measures (model $\mathrm{r}^{2}$ about 0.18 to 0.26 ), while the model $\mathrm{r}^{2}$ for tremor intensity in the nondominant hand was even lower (0.07) (table 8). Age, height, and serum albumen were significant predictors of vibratron threshold, while age, serum gamma glutamyl transferase, and height were significant predictors of tuning fork extinction time (table 8). Age was the strongest contributor to the models for both the vibratron threshold and the tuning fork extinction time, explaining $21 \%$ and $9 \%$ of the overall variance, respectively. There were no significant associations with long-term occupational exposure or with a past history of pesticide poisoning in the model. 
Table 8. Significant predictors of vibration sense and tremor intensity among the deciduous fruit farm workers. ${ }^{a}$ (GGT = gamma glutamyl transpeptidase)

\begin{tabular}{lcc}
\hline Outcome & Regression & $\begin{array}{c}\text { Partial correlation } \\
\text { coefficient }\end{array}$ \\
\hline $\begin{array}{l}\text { Vibratron threshold } \\
\text { (Log vib U) }\left(0.263^{b}\right)\end{array}$ & \\
Age & & \\
Height & +0.020 & 0.205 \\
$\quad$ Serum albumen & +0.015 & 0.034 \\
Tuning fork extinction & -0.023 & 0.017 \\
time (s) (0.176 $)$ & & \\
Age & & \\
Serum GGT & -0.096 & 0.086 \\
Height & +0.034 & 0.042 \\
Tremor intensity & -0.087 & 0.028 \\
Dominant hand $\left(0.198^{\circ}\right)$ & & \\
$\quad$ Height & & \\
$\quad$ Ever smoked & & \\
$\quad$ Organophosphate exposure & +0.584 & 0.062 \\
$\quad$ in past 10 days & +0.245 & 0.040 \\
Nondominant hand $\left(0.065^{\circ}\right)$ & & 0.035 \\
$\quad$ Schooling & -0.035 & 0.027 \\
\hline
\end{tabular}

a The forced regression models included age, education, past history of pesticide poisoning, lifetime alcohol consumption, recent organophosphate exposure, nonoccupational residential exposure, serum albumen and GGT, smoking status, reported exposure to organophosphate in past 10 days, reported number of days exposed to organophosphates in past season, height, number of past head injuries causing loss of consciousness, and long-term occupational organophosphate exposure (alternately cumulative or average intensity of organophosphate exposure). Only the variables with a regression coefficient significantly different from 0 at $P<0.05$ have been listed.

- Model correlation coefficient.

c Data on age for one subject unavailable - model, $\mathrm{N}=246$.

a Tremor intensity was log-transformed to achieve normalization. Nine subjects with visual acuity problems excluded from this analysis.

Similarly for tremor, no measures of long-term occupational exposure appeared to be significant. Small associations with tremor intensity in the dominant hand were demonstrated for height, ever smoking, and recent organophosphate exposure. Height was also marginally associated with poorer tremor score for the nondominant hand (OR $0.95,95 \%$ CI $0.91-0.99$ ) (table 9). Similarly, lifetime, potentially close residential exposure to agrichemicals was marginally associated with a poorer tremor score for the dominant hand (OR $0.95,95 \% \mathrm{CI}$ $0.92-0.98)$. Schooling also showed small associations with tremor outcomes.

\section{Discussion}

\section{Neurological symptoms}

The main findings of this study were the strong associations of current employment as an applicator and past poisoning by pesticides with increased neurological symptoms. Reports on increased symptoms related to organophosphate exposure in the absence of acute intoxication in the literature vary, either finding no increase in symptoms (45) or great inconsistency in the specific
Table 9. Predictors of tremor score among the deciduous fruit farm workers. ${ }^{2}(95 \% \mathrm{Cl}=95 \%$ confidence interval)

\begin{tabular}{lcc}
\hline Predictors & Odds ratio & $95 \% \mathrm{Cl}$ \\
\hline $\begin{array}{l}\text { Tremor score } \\
\text { bominant hand } \\
\quad \text { Schooling (years) }\end{array}$ & & \\
$\quad \begin{array}{l}\text { Lifetime close residential } \\
\text { exposure (years) }\end{array}$ & 1.18 & $1.05-1.32$ \\
Nondominant hand & 0.95 & $0.92-0.98$ \\
$\quad \begin{array}{l}\text { Alcohol consumed at } \\
\text { one sitting (g) }\end{array}$ & & \\
$\quad$ Height (cm) & 1.002 & $1.0005-1.004$ \\
\end{tabular}

a The forced regression models included age, education, past history of pesticide poisoning, lifetime alcohol consumption, recent organophosphate exposure, nonoccupational residential exposure, reported number of days exposed to organophosphates in past season, quantity of alcohol consumed at one sitting and long-term occupational organophosphate exposure (alternately cumulative or average intensity of organophosphate exposure). Only the variables with an odds ratio significantly different from 1 at $P<0.05$ have been listed. Data on age for one subject unavailable - model, $\mathrm{N}=246$.

t The tremor score was not amenable to normalization. The outcome was dichotomized as positive for subjects reaching the 6 th hole in the series of descending size order compared with those who only reached the 5th hole or fewer. Nine subjects with visual acuity problems were excluded from this analysis.

symptoms reported as more common $(15,46,47)$. In this study, the applicators consistently reported a wide range of neurological symptoms more commonly than the nonapplicators, and the result was statistically significant for dizziness, headache, sleepiness, and for the overall score for the neurological symptoms.

Competing explanations for the increase in symptoms may be related to nonchemical stresses of work (eg, long work shifts, tractor vibration, etc), psychosocial factors important to symptom generation (48) or reporting bias. However, the specificity of the association for neurological symptoms makes such confounding or bias unlikely. Indeed, applicators actually reported less earache, 1 of the 2 "dummy" symptoms inserted in the battery.

In contrast to current spray activity, previous poisoning by organophosphates is a different form of exposure requiring attention. The literature has documented the presence of affective changes and subjective symptoms among survivors of acute organophosphate pesticide poisoning $(16,22,49)$, as well as the presence of long-term neurobehavioral deficits $(20,21)$. Conspicuous in this study was a strong association between previous poisoning with pesticides and neurological symptoms (OR 4.08, 95\% CI 1.48-11.22). While data on the specific chemical agent responsible for the poisoning were not available, a review of the notifications of pesticide poisoning in the region (10) suggests that these events usually involve organophosphates.

Information bias in the form of systematic overreporting of symptoms by previously intoxicated workers needs to be considered. Head injury was associated with both neurological and "dummy" symptoms, the remarka- 
ble similarity in the measures of effect (odds ratios almost identical) suggesting that reporting bias was operating in relation to the "exposure" of head injury. However, this was not the case for past pesticide poisoning, where the association was specific for neurological symptoms only. Even if workers were aware of the types of pesticide-related effects being investigated, it is unlikely they would have been able to discriminate between specific neurotoxic symptoms and the nonspecific illness symptoms listed in the questionnaire. The specificity for neurological symptoms makes reporting bias unlikely. Nonetheless, subjective information has its limitations. Symptom outcomes accordingly are considered to carry relatively less weight in the interpretation of possible causal effects of chemicals in neurotoxicity assessment (50).

Misclassification of past poisoning due to an imprecise description as another possible explanation for the findings is unlikely, given the acceptable repeatability achieved for previous pesticide poisoning on the repeated questionnaires. In any event, such misclassification would be likely to be nondifferential and tend toward underestimating the strength of exposure-effect relationships. Moreover, the CAGE score, as a measure of excessive alcohol consumption, was moderately related to the neurological symptoms, an anticipated association. Given the consonance of past poisoning, current spray activity, and excessive alcohol consumption as predictors of neurological symptom outcomes, the evidence for a genuine exposure-effect relationship seems stronger and is further supported by the fact that head injury, by contrast, did indeed appear to lead to the overreporting of symptoms. Furthermore, there was also no expectation of compensation being offered, as such expectation might have been expected to influence the reporting of symptoms had it existed.

The symptom outcomes related to long-term exposure, when controlled for other predictors (including past poisoning) in the multiple logistic models, were not significantly associated with the neurological symptoms. Although the odds ratios for average lifetime intensity of exposure was nonsignificantly increased (OR 1.98, 95\% CI 0.49-7.94), it was also high for the "dummy" symptoms (OR 2.20, 95\% CI 0.55-9.88). The findings were similar when the analyses were rerun excluding workers with a history of past poisoning and those with clinical deficits (data not presented here). This finding suggests that the association between long-term low-dose organophosphate exposure in the absence of acute poisoning and neurological symptoms is either very weak or does not exist.

\section{Clinical outcomes}

While subclinical outcomes were the focus of our study, it is worth noting that all 5 subjects found to have evi- dence of clinical deficit on the neurological examination were current applicators. However, because of the small numbers involved, this association was not statistically significant and neither were any of the differences in the mean long-term organophosphate exposures for those with clinical deficit compared with those without. Despite the lack of a significant association, these findings may suggest some effect of agrichemical exposure since the direction of association between the clinical outcome and current status as an applicator remained positive after control for age and other confounders in the model. However, the study was not directed at detecting clinical effects, and power calculations were based on the anticipated abnormalities on subclinical tests.

The inclusion of subjects with clinical deficit in the modeling of the predictors of subclinical outcome could have led to an overestimation of a possible effect. For this reason, all the multivariate models showing significant associations with the occupational exposure variables were also analyzed excluding these subjects. In none of the cases in which associations with occupational exposure factors were demonstrated did the exclusion of the 5 subjects with a clinical deficit make any substantive difference to the results.

\section{Vibration sense and tremor}

None of the measures of long-term organophosphate exposure appeared to be significant in the multivariate modeling of the measures of vibration sense and tremor. The fact that known covariates of peripheral vibration sense, such as height and age, appeared as significant predictors suggests that the outcome measurement was accurate and standardized. The generally high alcohol intake level in this population, only $5 \%$ were nondrinkers and the mean daily consumption was about twice that of urban counterparts $(51,52)$, may have led to a masking of any long-term organophosphate exposure effects. It may also explain the contradictory findings of the alcohol effects on vibration sense (tables 8 and 9).

The measurement of vibration sense using the Vibratron II or tuning fork extinction time appeared to be equally useful methods in this study. Age and height, known predictors of vibration sense, were significant covariates with both methods. The simplicity of the tuning fork may confer logistical advantages for studies measuring peripheral vibration sense in settings in which electric power is unavailable, or when high-technology instrumentation is unaffordable, as may be commonly encountered in developing countries.

Tremor intensity in the dominant hand was found to be related to a history of organophosphate exposure as reported by the farmer for the preceding 10 days. This figure suggests some acute agrichemical exposure effect, but this effect was small (less than $3 \%$ of the variance explained). Findings of increased tremor using a clinical 
measure have also been reported for production workers chronically exposed to organophosphates and other agrichemicals when compared with textile workers (15).

However, tremor as an effect of long-term agrichemical exposure has not been explored in the few studies of survivors of acute poisoning, nor has the quantitation of tremor been widely used in studies of workers exposed to organophosphates. The association of height with tremor intensity in the dominant hand and with the tremor score of the nondominant hand (table 8) is similar in direction and strength to the associations of height with vibration sense measures. Given the recognized value of tests of peripheral vibration sense in the early detection of the effects of exposure to chemical neurotoxins, this association between height and motor tremor (table 8) may indicate grounds for developing further the use of tremor measurement as a survey device in occupational neurotoxicity. Factors to take into account in the use of tremometry would be the role of smoking status as a confounder (table 8) or artefactual association arising from the biomechanics of the test, which requires the subject to avoid resting his or her elbow.

\section{Representativity of the sample}

Nonresponse in this study exceeded $30 \%$ of farms and applicators and may have reduced the representativity of the study sample. Smaller farms may have poorer safety measures, which may have resulted in a best-case scenario in this study. A previous review of notifications reported to the regional department of health for the period 1987-1991 (10) did not demonstrate the presence of any previous reported pesticide poisoning on these nonresponding farms, although smaller farms may well underreport such poisonings to statutory authorities. However, given that the mean educational level of this group [5.1 (SD) 2.9 years] was comparable with results from other studies of farm workers in the Western Cape Province (53), there is some evidence supporting a reasonable degree of representativity of the study sample.

\section{Undernutrition and environment}

The measures of long-term environmental organophosphate exposure showed little relationship to neurological outcomes, except for the tremor score of the dominant hand, poorer performance on the test being associated with longer lifetime residence in proximity to a sprayed farm. Few studies have examined the impact of nonoccupational agrichemical exposure in studies of rural workers, and this finding may suggest that this route of exposure needs further investigation. However, this finding was also an isolated one and may well have arisen due to the chance effects of multiple comparisons.

Another finding of significance was the role of serum albumen as a predictor of vibratron outcomes. Given high levels of deprivation in developing countries (eg, there was substantial stunting in the sample and about $17 \%$ of subjects were anemic), widespread adult and child undernutrition as a confounder for neurobehavioral assessment requires careful attention in future epidemiologic studies.

\section{Concluding remarks}

The data from this study examining symptom, vibration sense, and tremor outcomes after control for acute exposure and past pesticide poisoning did not demonstrate consistent adverse effects of long-term organophosphate exposure. Current employment as a spray applicator appeared to be associated with an increase in neurological symptoms and a nonsignificant increase in the prevalence of clinical neurological deficits. In addition, increased reporting of neurological symptoms appeared to be associated with past pesticide poisoning. However, no relationship between long-term exposure was demonstrated with the "harder" outcome measures of vibration sense impairment or motor tremor.

\section{Acknowledgments}

This study was supported by research grants from the International Development Research Centre (IDRC Canada), the South African Medical Research Council, and by the Guy Elliot Research Fellowship in the Department of Medicine at the University of Cape Town.

The authors wish to thank Ms G Joubert of the Department of Biostatistics in the Medical Faculty of the University of the Free State for kindly providing the SAS program used to calculate the confidence intervals for the kappa statistic and Ms Aneleh Midgeley for her assistance in preparing the manuscripts.

\section{References}

1. Pesticides Trust, Review of the global pesticide market. Pestic News 1993;22:11,13.

2. British Medical Association. Pesticides, chemicals and health. Kent: Edwin Arnold, 1992.

3. London L. Agrichemical hazards in the South African farming sector. S Afr Med J 1992;81:560—4.

4. Singh PDA, West ME. Acute pesticide poisoning in the Caribbean. West Indian Med J 1985;34:75-83.

5. Jeyaratnam J. Health problems of pesticide usage in the third world. Br J Ind Med 1985;42:505-6.

6. Osorio AM, Ames RG, Rosenberg J, Mengle D. Investigation of a fatality among parathion applicators in California. Am J Ind Med 1991;20:533-46.

7. Baker EL, Zack M, Miles JW, Alderman L, Warren M, Dobbin RD, et al. Epidemic malathion poisoning in Pakistan malaria workers. Lancet 1978;1:31-3.

8. Brown SK, Ames RG, Mengle DC. Occupational illness from 
cholinesterase-inhibiting pesticides among agricultural applicators in California, 1982-1985. Arch Environ Health 1989:44:34-9

9. Fillimore CM, Lssenger JE. A cholinesterase testing programme for pesticide applicators. J Occup Med 1993;35: $61-70$.

10. London L, Ehrlich R, Rafudien S, Krige F, Vurgarellis P. Pesticide poisoning notification in the Western Cape 19871991. S Afr Med J 1994;84:269-72.

11. Richter ED, Chuwers P, Levy Y, Gordon M, Graver F, Marzouk J, et al. Health effects from exposure to organophosphate pesticides in workers and residents in Israel. Isr J Med Sci 1992;28:584-97.

12. Bertazzi PA, Zochetti C, Pesatori AC, Guercilena S, Sanarico M, Radice L. Ten-year mortality study of the population involved in the Seveso incident in 1976. Am J Epidemiol 1989; 129:1187-200.

13. Berberian IG, Enan EE. Neurotoxic studies in humans occupationally exposed to pesticides. J Soc Occup Med 1987;37: $126-7$.

14. Zober A, Messerer P, Huber P. Thirty four year mortality follow up of BASF employees exposed to 2,3,7,8-TCDD after the 1953 accident. Int Arch Occup Environ Health 1990;62: 139-57.

15. Otto D, Soliman S, Svensgaard D, Soffar A, Ahmed N. Neurobehavioral assessment of workers exposed to pesticides. In: Johnson BL, Anger WK, Durao A, Xintaras C, editors. Advances in neurobehavioral toxicology: applications in environmental and occupational health. Chelsea (MI): Lewis Publishers, 1990:305-22.

16. Rosenstock L, Kiefer M, Daniell W, McConnell, Claypole K. Chronic central nervous system effects of acute organophosphate pesticide exposure. Lancet 1991;338:223-7.

17. Daniell W, Barnhart S, Demers P, Costa LG, Eaton DL, Miller M, et al. Neuropsychological performance among agricultural pesticide applicators. Environ Res 1992;59: 217-28.

18. Davies JE. Neurotoxic concerns of human pesticide exposures. Am J Ind Med 1990;18:327-31.

19. Namba T, Nolte CT, Jackrel JD, Grob D. Poisoning due to organophosphate insecticides: acute and chronic manifestations. Am J Med 1971;50:475-91.

20. Savage EP, Keefe TJ, Mounce LM, Lewis JA, Burcar PJ. Chronic neurological sequaelae of organophosphate pesticide poisoning. Arch Environ Health 1988;43:38 - 45.

21. Steenland K, Jenkins B, Ames RG, O'Malley M, Chrislip D, Russo J. Chronic neurological sequelae to organophosphate pesticide poisoning. Am J Public Health 1994;84:731-6.

22. Rosenstock L, Daniell W, Barnhart S, Schwartz D, Demers PA. Chronic neuropsychological sequelae of occupational exposure to organophosphate insecticides. Am J Ind Med $1990 ; 18: 321-5$.

23. Stephens R, Spurgeon A, Calver IA, Beach J, Levey LS, Berry $H$, et al. Neuropsychological effects of long-term exposure to organophosphates in sheep dip. Lancet 1995;354: 1135-9.

24. Blair A, Zahm S. Methodological issues in exposure assessment for case-control studies of cancer and herbicides. Am J Ind Med 1990;18:285-93.

25. Maroni M, Fait A. Health effects in man from long-term exposure to pesticides: a review of the 1975-1991 literature. Toxicology 1993;78:1-174.

26. Keenan J, Sarakinsky M. Reaping the benefits: working conditions in agriculture and the bantustans. In: Moss G, Obery
I, editors. South African review 4. Johannesburg: Raven Press, 1987:581.

27. London L, Nell V, Taylor T, Thomson ML, Myers JE. An investigation into neurological and neurobehavioral effects of long-term agrichemical use among deciduous fruit farm workers in the Western Cape, South Africa. Environ Res. In press.

28. London L, Myers JE. Agrichemical usage patterns and workplace exposure in the major farming sectors in the Southern Region of South Africa. South Afr J Sci 1995;91:515-22.

29. Johnson BL, Baker EL, Batawi ME, Gilioli R, Hänninen $H$, Seppäläinen AM, et al, editors. Prevention of neurotoxic illness in working populations. New York (NY): John Wiley and Sons, 1987.

30. Hooisma J, Emmen HH, Kulig BM, Muijser H, Poortvliet D. Factor analysis of tests from the neurobehavioral evaluation system and the WHO neurobehavioral core test battery. In: Johnson BL, editor. Advances in neurobehavioral toxicology: applications in environmental and occupational health. Chelsea (MI): Lewis, 1990:245-55.

31. Cassito MG, Camerino D, Hänninen H, Anger WK. International collaboration to evaluate the WHO neurobehvioural core test battery. In: Johnson BL, editor. Advances in neurobehavioral toxicology: applications in environmental and occupational health. Chelsea (MI): Lewis, 1990.

32. He F, Zhang S, Li G, Zhang Z, Dong $X$, Wang $H$, et al Assessment of the adverse effects of acrylamide on occupationally-exposed workers - neurological and electroneuromyographical studies. In: Johnson BL, editor. Advances in neurobehavioral toxicology: applications in environmental and occupational health. Chelsea (MI): Lewis, 1990:37787.

33. Nell V, Myers JE, Colvin M, Rees D. Neuropsychological assessment of organic solvent effects in South Africa: test selection, adaptation, scoring and validation issues. Environ Res 1993;63:301-18.

34. Weidepoel L. Learning from a literacy project: a survey of adult literacy in South Africa. Cape Town: Centre for ExtraMural Studies, University of Cape Town, 1984.

35. Minton NA, Murray VSG. A review of organophosphate poisoning. Med Toxicol 1988;3:350—75.

36. Knedel M, Bottger R. Eine Kinetische Methode zur Bestimmung der Aktivitat der pseudocholinesterase (Acylcholinacythdrolase 3.1.1.8.). Klin Wochenschr 1967;45:325-7.

37. London L, Thomson ML, Sacks S, Fuller B, Bachmann OM, Myers JE. Repeatability and validity of a field kit for estimation of cholinesterase in whole blood. Occup Environ Med 1995;52:57-64

38. Scully P. Liquor and labour in the Western Cape, 18701900. In: Crush J, Ambler C, editors. Liquor and labour in Southern Africa. Athens (OH): Ohio University Press, 1992: 56.

39. Mayfield DG, Mcleod G, Hall P. The CAGE questionnaire: validation of new alcoholism screening instrument. Am J Psychiatry 1974;131:1121-3.

40. Setzer ML. The Michigan alcoholism screening test: the quest for a new diagnostic instrument. Am J Psychiatry 1971;127: 1653-8.

41. Bachmann O, De Beer Z, Myers JE. n-Hexane neurotoxicity in metal can manufacturing workers. Occup Med 1993;43: $149-54$.

42. Gerr FE, Letz R. Reliability of a widely used test of peripheral cutaneous vibration sensitivity and a comparison of two testing protocols. Br J Ind Med 1988;45:635-9. 
43. SAS Insitute Inc. SAS/STAT user's guide, version 6.08. 4th ed. Cary: SAS Insitute Inc, 189.

44. Fleiss JL. Statistical methods for rates and proportions. 2nd ed. New York (NY): John Wiley, 1981:212.

45. Maizlish N, Schenker M, Weisskopf C, Selber J, Samuels S A behavioral evaluation of pest control workers with shortterm, low-level exposure to the organophosphate diazinon. Am J Ind Med 1987;12:153-72.

46. Richter E. Organophosphorus pesticides: a multinational epidemiologic study. Copenhagen: European Occupational Health Programme, World Health Organization, 1993.

47. Stokes L, Stark A, Marshall E, Narang A. Neurotoxicity among pesticide applicators exposed to organophosphates. Occup Environ Med 1995;52:648-53.

48. Spurgeon A, Gompertz D, Harrington JM. Modifiers of nonspecific symptoms in occupational and environmental syndromes. Occup Environ Med 1996;53:361-6.

49. Levin HS, Rodnitzky RL, Mick DL. Anxiety associated with exposure to organophosphorus compounds. Arch Gen Psychiatry $1976 ; 33: 225-8$.

50. Simonsen L, Johnsen H, Lund SP, Matikainen E, Midtgård
U, Wennberg A. Methodological approach to the evaluation of neurotoxicity data and the classification of neurotoxic chemicals [review]. Scand J Work Environ Health 1994; 20:1-12.

51. Wolmarans P, Langenhoven ML, Benade AJS, Swanepoel ASP, Kotze TJvW, Rossouw JE. Intake of macronutrients and their relationship with total cholesterol and high-density lipoprotein cholesterol: the coronary risk factor study, 1979. S Afr Med J 1988;73:12-15.

52. Bourne L, Langenhoven ML, Steyn K, Jooste PL, Laubscher JA, Van der Vyfer E. Nutrient intake in the urban African population of the Cape Peninsula, South Africa: the BRISK study. Cent Afr J Med 1993;39:238— 47.

53. De Graaff JF, Louw W, Van der Merwe M. Farm schools in the western cape: a sociological analysis. Stellenbosch: Research Unit for Sociology of Development, University of Stellenbosch, 1990. Department of Sociology, occasional paper no 14.

Received for publication: 14 February 1997 